\title{
Characterizing the bull shark Carcharhinus leucas habitat in Fiji by the chemical and isotopic compositions of their teeth
}

\author{
László Kocsis • Torsten W. Vennemann • \\ Alex Ulianov • Juerg M. Brunnschweiler
}

Received: 15 August 2014 / Accepted: 26 January 2015 /Published online: 7 February 2015

(C) Springer Science+Business Media Dordrecht 2015

\begin{abstract}
Bull sharks Carcharhinus leucas use estuarine and riverine systems as nursery habitat. The Shark Reef Marine Reserve (SRMR) on the southern coast of Viti Levu, Fiji, is well-known for its adult bull shark population. The species' seasonal departure from the SRMR is related to reproductive activity, but nursery grounds have not yet been identified on the southern coast of Viti Levu. In order to further identify and characterise bull shark habitats in Fiji, 49 teeth were collected from bull sharks encountered at the SRMR and measured for their trace element concentrations, and 22 of them for oxygen isotopic composition in the phosphate group of bioapatite. The trace element analyses yielded relatively high $\mathrm{Na}, \mathrm{Mg}$, $\mathrm{Sr}$, and $\mathrm{F}$ and low
\end{abstract}

Electronic supplementary material The online version of this article (doi:10.1007/s10641-015-0386-4) contains supplementary material, which is available to authorized users.

L. Kocsis $(\bowtie) \cdot$ A. Ulianov

Institute of Earth Sciences, UNIL-GEOPOLIS, University of

Lausanne, Lausanne, Switzerland

e-mail: laszlokocsis@hotmail.com

T. W. Vennemann

Institute of Earth Surface Dynamics, UNIL-GEOPOLIS,

University of Lausanne, Lausanne, Switzerland

J. M. Brunnschweiler

Gladbachstrasse 60, 8044 Zurich, Switzerland

L. Kocsis

Geology Group, Faculty of Science, Universiti Brunei

Darussalam, Gadong, Brunei Darussalam
Ba concentrations for all the teeth supporting formation in marine environment. The phosphate oxygen isotope data concur with this result and the data evidently show that these teeth developed under marine condition relating to the temperature and oxygen isotopic composition of Fiji's coastal waters. Therefore, the investigated teeth show no signs of freshwater habitat. Our results do not support the hypothesis that bull sharks enter freshwater habitats, at least not for longer time periods, during their absence from the SRMR. Additionally, the bull shark teeth had unexpectedly high zinc concentration at the very edge of the enameloid. This cannot be explained by environmental factors; therefore the high $\mathrm{Zn}$ content is interpreted here as a result of biological process, a reflection of enzyme (i.e., KLK4) related organic matter removal and enhanced crystallization during tooth maturation.

Keywords Shark teeth · Trace elements · Oxygen isotopes in phosphate $\cdot$ Zinc concentration $\cdot$ Shark Reef Marine Reserve

\section{Introduction}

Organisms actively interact with their environment when developing soft and hard tissues by, for example, taking up elements and compounds as nutrients from their habitat. Hence, organic and inorganic compounds can be used as archives that provide information about the conditions under which tissues were formed. In the case of aquatic animals, chemical and isotopic 
compositions of skeletal parts (teeth, scales, bones, otoliths) or soft tissues (muscle, collagen) can be used to trace habitats or discern migration (Edmonds et al. 1996; Gillanders et al. 2001; Vennemann et al. 2001; Outridge et al. 2002; McMeans et al. 2007; Shephard et al. 2007; MacKenzie et al. 2011; Tsukamoto et al. 2014). Diadromous fish can both live in freshwater and in the ocean (Daclusi and Kerebel 1980; Koch et al. 1992; Tillett et al. 2011). Due to the large compositional differences (elemental and isotopic) between seawater and freshwater (Epstein and Mayeda 1953; White 1998; Bruland and Lohan 2003; Gaillardet et al. 2003; Hoefs 2004), mineralized tissues such as teeth of individuals of diadromous species may record different trace elements and be of different isotopic composition depending on the type of habitat they were formed in.

An example of a diadromous elasmobranch species is the bull shark Carcharhinus leucas. Bull sharks are widespread in tropical and subtropical seas, and the only wide-ranging shark species that penetrates far into freshwater rivers and apparently is able to exist there at length (Compagno 1984). The reproductive biology of the bull shark is little understood. Both sexes reach maturity at $\sim 200 \mathrm{~cm}$, gestation time is suggested to be 10-11 months, and parturition occurs in spring to summer (CruzMartínez et al. 2005). Like numerous other carcharhinid sharks, bull sharks use coastal areas, including estuaries and river systems, as nursery habitat (Heupel et al. 2010; Curtis et al. 2011; Tillett et al. 2012).

All shark species have multiple rows of teeth in both upper and lower jaws. Functional teeth are erect at the outer margin of the jaw. Replacement teeth are recumbent against the jaw surface (Kemp 1999). Teeth are anchored in the connective tissue covering the jaw cartilage but are continually being pulled forward as they mature. Functional teeth eventually become detached and are replaced by the generation of teeth next in line behind them (Kemp 1999). Although no data are currently available for the bull shark, sharks generally replace their teeth rapidly (e.g., Motta and Wilga 2001). This in principle allows recording changes in chemical/ isotopic signals of teeth formed under different environmental conditions.

Shark teeth are made up of biologically synthesized apatite crystals formed in an organic matrix. The crown of the teeth is covered by an outer enameloid layer of larger crystal size with low organic matter content ( $\sim 1$ weight $\%$ ), while the internal part and the root consist of dentine with smaller crystallites and an organic matrix of up to $20 \mathrm{wt} . \%$ (Elliott 2002; Skinner and Jahren 2007). The mineralogy of enameloid is fluor-apatite $\left[\mathrm{Ca}_{5}\left(\mathrm{PO}_{4}\right)_{3} \mathrm{~F}\right]$ (Moller et al. 1975; Daclusi and Kerebel 1980), with only minor amounts of hydroxyl- and carbonate-ion substitution for the fluorine and phosphate sites, respectively (Miake et al. 1991; Dahm and Risnes 1999). Calcium is the major cation but it can be replaced by many other elements (e.g., $\mathrm{Na}, \mathrm{Sr}, \mathrm{Ba}$, $\mathrm{Mn})$ and some can reach concentrations of several $1000 \mathrm{ppm}$ in modern teeth (e.g., Vennemann et al. 2001; Elliott 2002; Skinner and Jahren 2007). Some of these elements can be enriched and/or depleted in the apatite matrix depending on the ambient environment and for example higher $\mathrm{Sr}$ and lower $\mathrm{Ba}$ concentration would be expected in case of marine habitat compare to freshwater one.

The oxygen isotope composition of phosphate in fish teeth is a function of the oxygen isotopic composition of the ambient water and temperature (e.g., Longinelli and Nuti 1973; Kolodny et al. 1983). The average oxygen isotope composition $\left(\delta^{18} \mathrm{O}\right)$ of seawater is rather stable but it can be relatively enriched in the heavier oxygen isotopes due to evaporation or relatively depleted therein due to freshwater input. Hence, teeth mineralized in marine waters will also have a higher ${ }^{18} \mathrm{O}$-content compared to those that were formed in freshwater-influenced environments (e.g., Kocsis et al. 2007; Klug et al. 2010; Fischer et al. 2011).

In Fiji, as part of a small-scale conservation project, adult bull sharks have been studied at a shark feeding site in the Shark Reef Marine Reserve (SRMR) on the southern coast of Viti Levu (Brunnschweiler 2010, Fig. 1). The bull shark population encountered at the SRMR shows a femalebiased sex ratio (Brunnschweiler and Baensch 2011). Direct diver observations confirmed that bull shark numbers increased over the years (Brunnschweiler and Baensch 2011; Brunnschweiler et al. 2014), but numbers decrease over the course of a calendar year (Brunnschweiler and Baensch 2011). The species' seasonal departure from the feeding site is related to reproductive activity (Brunnschweiler and Baensch 2011).

Shark fishing is banned in the so-called Fiji Shark Corridor on the southern coast of Viti Levu 
Fig. 1 Geographic positions of the sites from where shark teeth were obtained. (a) Map of Fiji.

Star shows the Shark Reef Marine Reserve where the bull shark teeth were collected. Water samples came from the following rivers: 1 . Nadi; 2. Sigatoka; 3. Navua; 4.

Rewa; 5. Ba; 6. Vitogo; 7.

Dreketi. (b) World map. 1. Fiji Islands; 2. Tonga; 3: Brisbane River, Australia; 4. South Africa; 5. Florida; 6. Lake Nicaragua; 7. Budapest - aquarium specimens. See also Supplementary Tables 4 and 5 in Online Resource 2
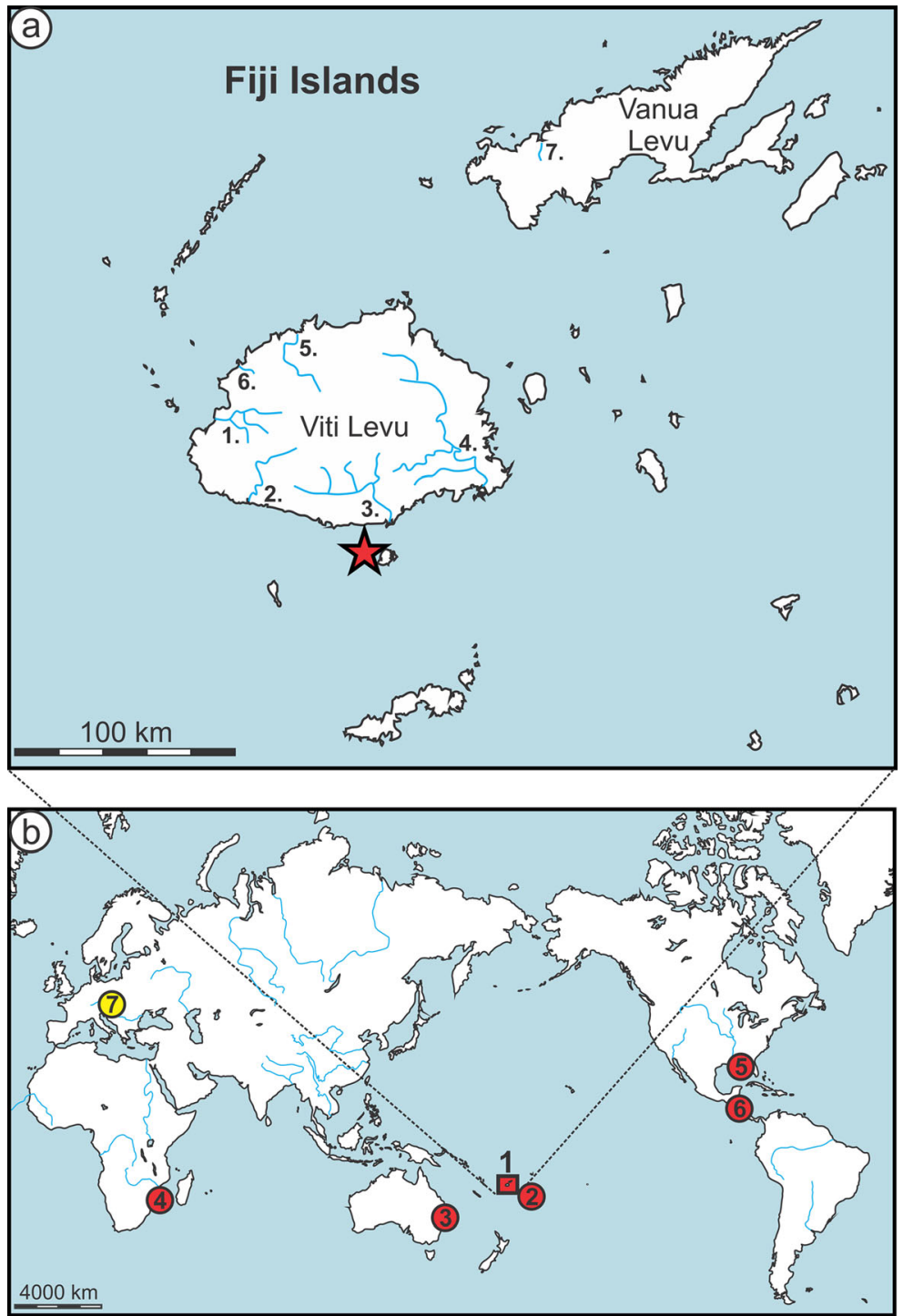

(Brunnschweiler 2010). But in order to fully protect the species, all stages of its life-cycle must be protected. Hence, it is of utmost importance that pupping and nursery areas are known. Such information is currently lacking for bull sharks in Fiji. Similar to other geographic populations, they may use riverine or estuarine waters that offer a suitably protected habitat for juveniles (Simpfendorfer et al. 2005; Heupel and Simpfendorfer 2008; Heupel et al. 2010; Rasalato et al. 2010; Curtis et al. 2011). Here, we test the hypothesis that bull sharks enter freshwater rivers when they are mostly absent from the SRMR at the end of a calendar year by examining their teeth for signs of a compositional indicator for freshwater tooth mineralization.

\section{Materials and methods}

Bull sharks are offered whole fish heads by a feeder in the SRMR (Brunnschweiler 2010). When the bull sharks feed on fish heads, they sometimes lose one or several teeth in the process of feeding as shown in the animation (Online Resource 1). A total of 49 such teeth were collected in the months of January to March in $2005(n=2), 2009(n=42)$ and $2010(n=5)$. During these 
months of the year, bull sharks reappear at the feeding site in the SRMR, presumably returning from reproduction sites (Brunnschweiler and Baensch 2011). For comparative purposes, teeth of adult and juvenile bull sharks were obtained from Tonga $(n=1)$, Florida $(n=1)$, Lake Nicaragua $(n=1)$, Brisbane River $(n=2)$ and from South Africa $(n=1)$, together with additional teeth from other species held in the aquarium of the Tropicarium in Budapest, Hungary (a tooth of a sandbar shark Carcharhinus plumbeus and three teeth of sandtiger sharks Carcharias taurus). All samples are also listed in Supplementary Tables 1 and 4 in Online Resource 2.

To analyse the chemical compositions of the teeth, they were washed in distilled water and their tips were cut off and embedded in resin and polished to provide a flat surface (Fig. 2). The major-element concentrations were determined using wavelength-dispersive analysis of an electron microprobe (EMPA), while trace element compositions were analysed by laser-ablationinductively coupled plasma-mass-spectrometry (LAICP-MS, for details see Online Resource 3). For stable isotope analyses, the enameloid was grated off the surface of the teeth by a micro-drill and for some teeth the root was also sampled for comparison. The fine-grained powder was pre-treated following the methods of Koch et al. (1997) in order to remove organic matter. The cleaned powder was dissolved in $\mathrm{HF}$ and the $\mathrm{PO}_{4}{ }^{3-}$ group was precipitated as silver-phosphate (e.g., Crowson et al. 1991; Dettman et al. 2001). The oxygen isotope measurement was made using a hightemperature conversion elemental analyzer coupled to an isotope ratio mass spectrometer (for details see Online Resource 3). Oxygen isotope compositions are expressed in the familiar $\delta$-notation relative to Vienna Standard Mean Ocean Water (VSMOW) and are expressed as variations in parts per thousand (\%o) as follows $\delta^{18} O=\left(\frac{\left({ }^{18} O /{ }^{16} O\right)_{\text {Sample }}}{\left(\left({ }^{18} \mathrm{O} /{ }^{16} \mathrm{O}\right)_{\text {VSMOW }}\right.}-1\right) \times 1000$.

Waters from the feeding site at the SRMR as well as from several Fijian rivers were collected and measured for their oxygen isotope composition and trace element content (Fig. 1a). Some water samples were also obtained from the Tropicarium, where the tanks are filled by local freshwater and to which the salts are added, and one sample came from the Brisbane River in Australia (see Supplementary Tables 4 and 5 in Online Resource 2, and for analytical details see Online Resource 3).

\section{Results}

Fiji bull shark teeth

The major element concentrations of tooth enameloid have a limited range with averages of $53.5 \pm 0.4 \mathrm{wt} . \%$, $41.3 \pm 0.3$ wt. $\%$ and $3.8 \pm 0.2$ wt. $\%$ for $\mathrm{CaO}, \mathrm{P}_{2} \mathrm{O}_{5}$ and $\mathrm{F}$, respectively. Sixteen trace elements ( $\mathrm{Li}, \mathrm{B}, \mathrm{Na}, \mathrm{Mg}, \mathrm{S}$, $\mathrm{Mn}, \mathrm{Fe}, \mathrm{Ni}, \mathrm{Cu}, \mathrm{Zn}, \mathrm{Rb}, \mathrm{Sr}, \mathrm{Y}, \mathrm{Ba}, \mathrm{La}, \mathrm{U})$ were analysed for and all have concentrations above their detection limits. The results are listed in Supplementary Table 1 in Online Resource 2. Most of the data represent the average of $2-5$ spot measurements. In some teeth, element concentrations can differ within individual specimens, giving a high relative standard deviation ( $\mathrm{rsd} \%)$. Elements that may likely be discriminative between

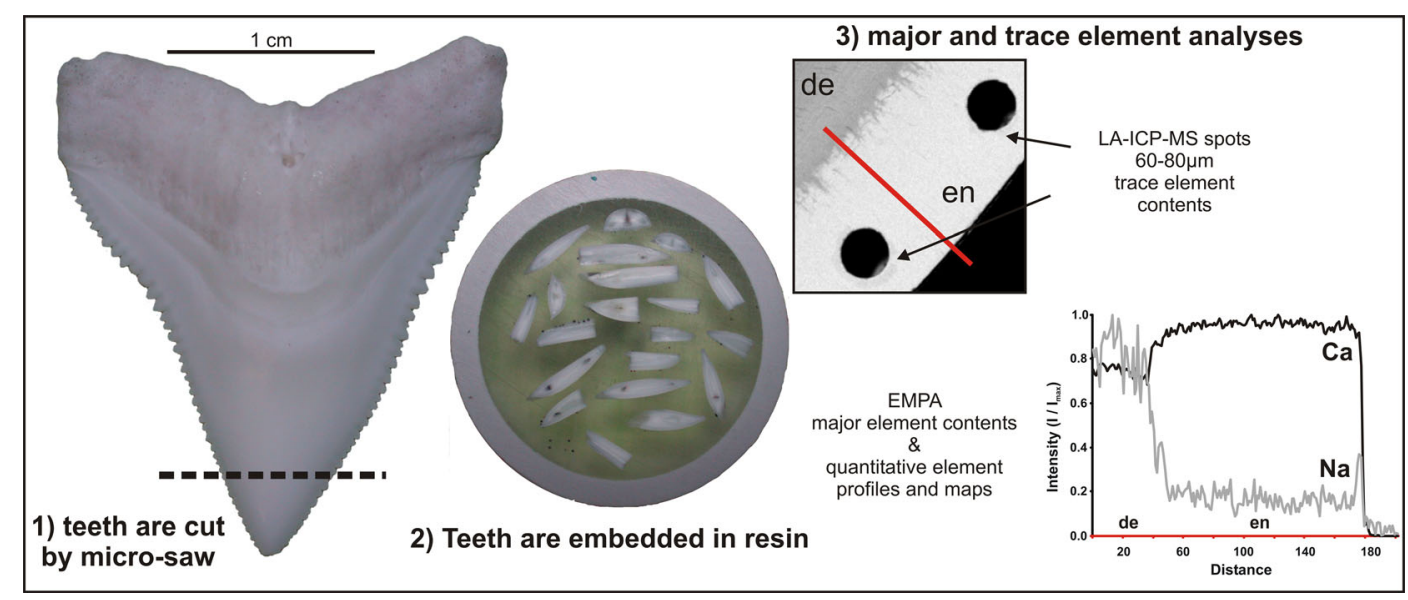

Fig. 2 Preparation of the teeth for major and trace element compositions. Abbreviation: en enameloid, de dentine 


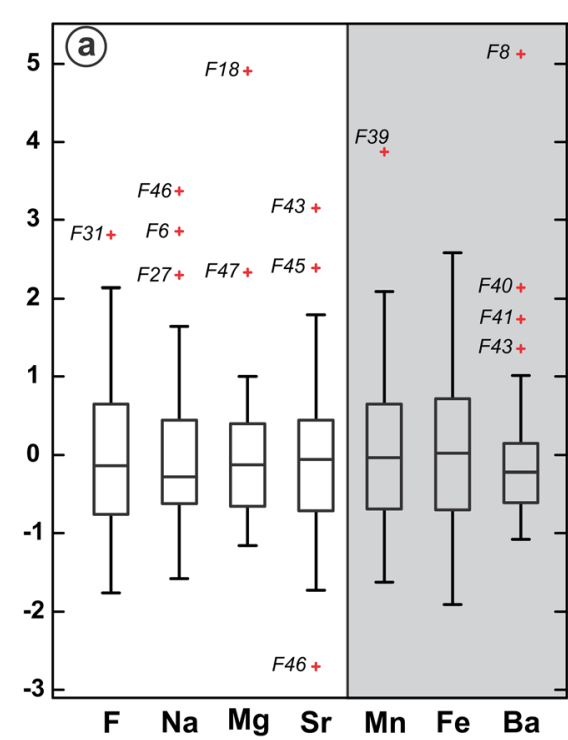

Fig. 3 (a) Box-plots of standardized concentrations of seven, possibly the most discriminative elements (F, Na, Mg, Mn, Fe, Sr, Ba, for different habitats, in the Fiji shark teeth. Grey shaded area for $\mathrm{Mn}, \mathrm{Fe}$ and $\mathrm{Ba}$; these are expected to have higher concentration in

marine and freshwater environments include $\mathrm{F}, \mathrm{Na}, \mathrm{Mg}$, $\mathrm{Sr}, \mathrm{Mn}, \mathrm{Fe}$, and $\mathrm{Ba}$, and their variations are shown as boxplots in Fig. 3a. Some teeth have unexpectedly high $\mathrm{Zn}$ concentrations (>1300 ppm), and similar to other elements (e.g., $\mathrm{Li}, \mathrm{Na}, \mathrm{Mg}, \mathrm{Mg}$ ) larger internal variations. Elements with sufficiently high concentrations were mapped by electron microprobe and differences in concentration between enameloid and dentine were measured. $\mathrm{Na}$ and $\mathrm{Mg}$ are more enriched, while $\mathrm{Ca}, \mathrm{F}$ and $\mathrm{Zn}$ are relatively depleted in the dentine when

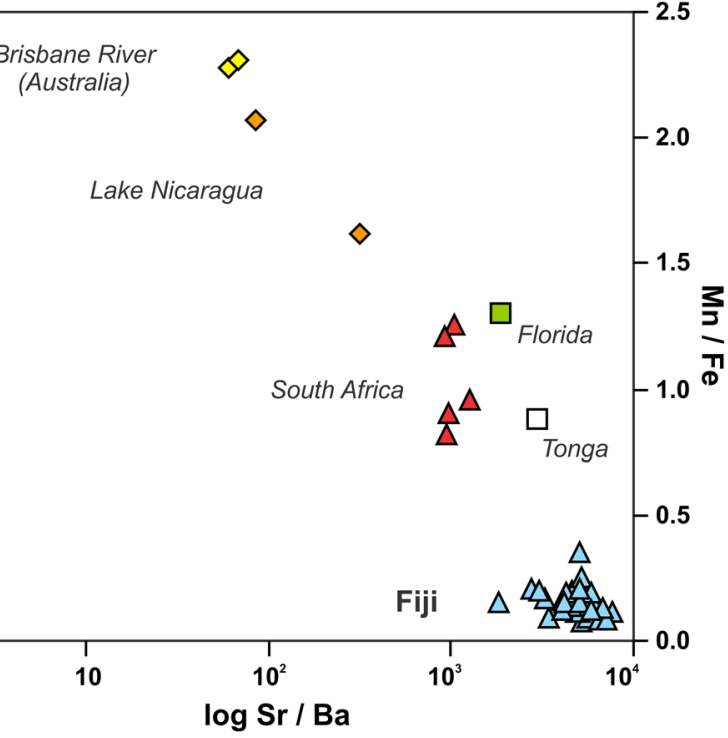

a freshwater related environment opposite to the other elements. (b) $\log \mathrm{Sr} / \mathrm{Ba}$ vs. $\mathrm{Mn} / \mathrm{Fe}$ plot. Note the clear separation of the teeth according to their origin

compared to enameloid (Fig. 4). Zn has the highest concentrations at the extreme outside of the teeth and its concentration decreases exponentially towards the inside of the teeth (Fig. 5). The enameloid at the extreme outside has the highest concentration, which is best reflected by analyses at the tooth serrations (Fig. 6). Laser-ablation analyses also indicate that besides $\mathrm{Zn}$, $\mathrm{Li}$ and $\mathrm{Mn}$ are also more enriched in this part.

A log-normalized correlation matrix for 18 variables of major and trace elements is shown in Supplementary
Fig. 4 Microprobe element distribution maps (Ca, P, F, Na, $\mathrm{Mg}$ and $\mathrm{Zn}$ ) on the example of tooth F28. All analysed teeth yielded similar distributions. The brighter the image is the higher the concentration of the given elements. Note that enameloid is more enriched in $\mathrm{Ca}$ and $\mathrm{F}$, while dentine has higher $\mathrm{Na}$ and $\mathrm{Mg}$ concentrations. $\mathrm{Zn}$ is only enriched at the edge of the tooth. Scale bar is $1 \mathrm{~mm}$
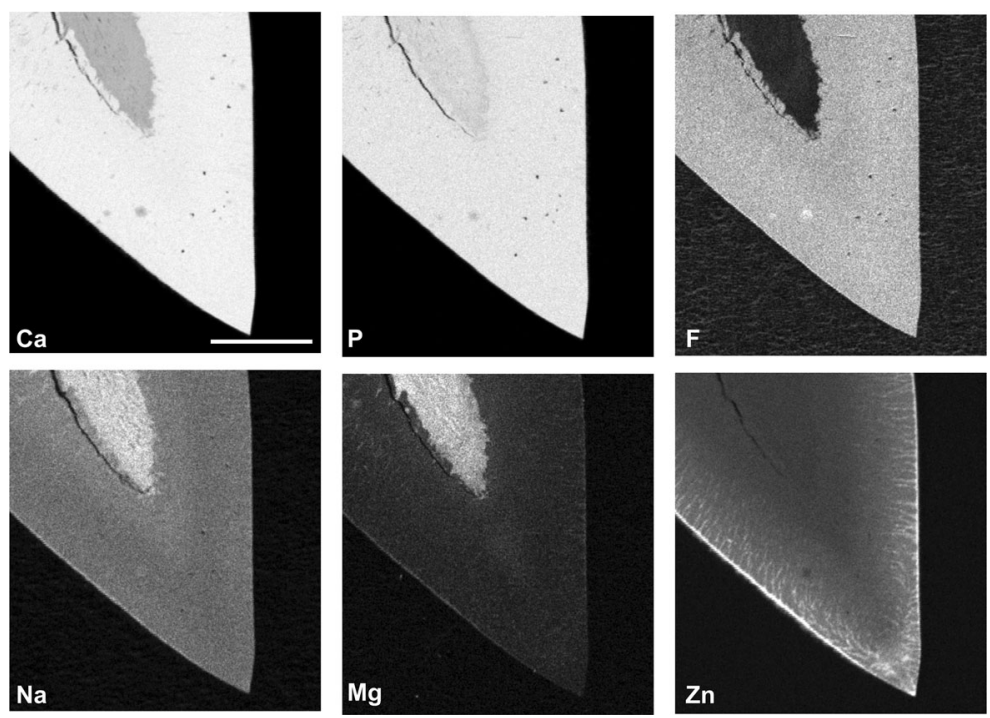

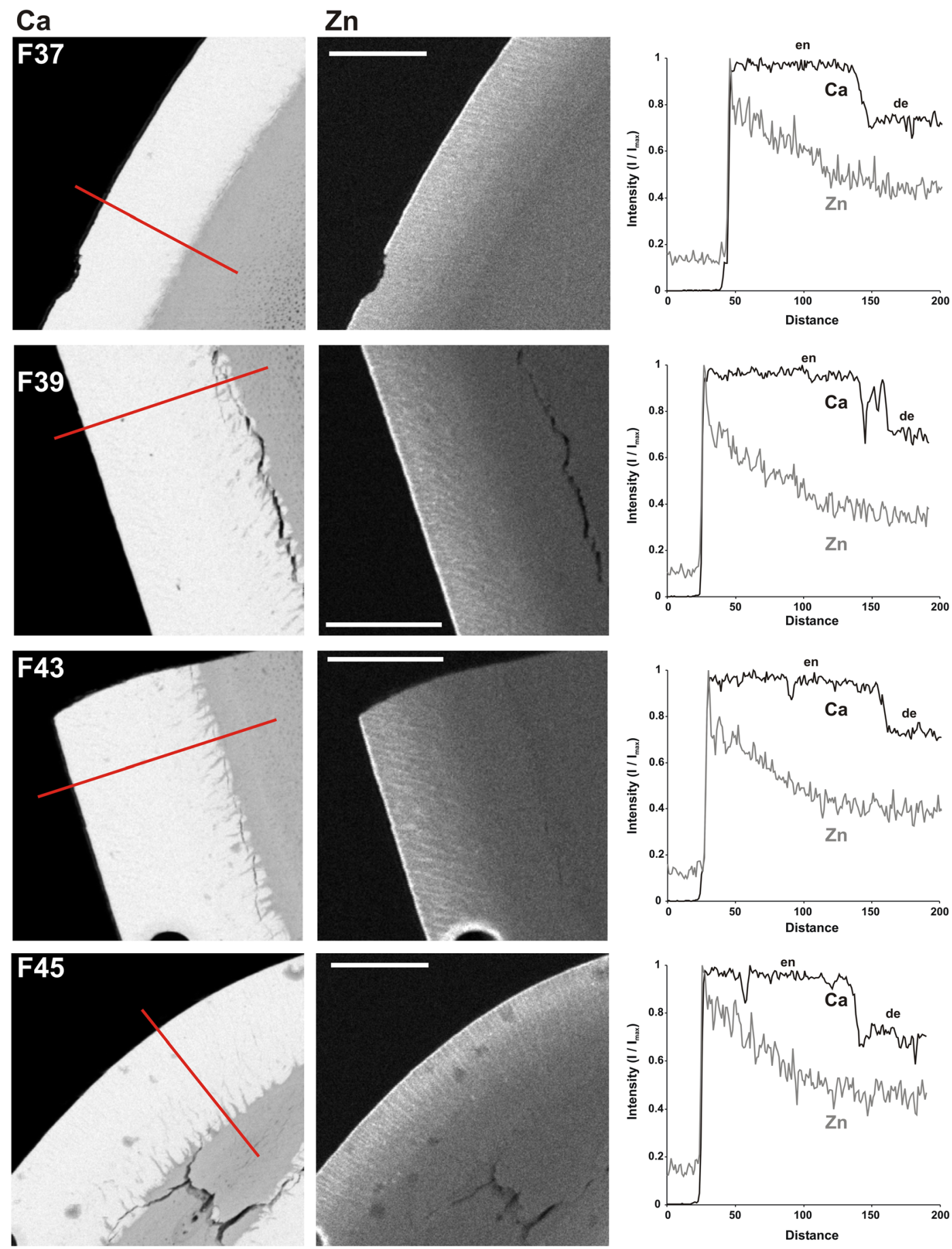

Fig. 5 Microprobe element maps of $\mathrm{Ca}$ and $\mathrm{Zn}$ with intensity profiles from four examples of Fiji teeth. Red lines show where the intensity profiles were obtained by ImageJ software. Abbreviation: en enameloid, de dentine. Scale bar is $1 \mathrm{~mm}$

Table 2 in Online Resource 2. Positive correlations $\left(\mathrm{r}^{2}>\right.$ 0.6) exist between the $\mathrm{CaO}-\mathrm{P}_{2} \mathrm{O}_{5}, \mathrm{Rb}-\mathrm{Sr}$ and $\mathrm{B}-\mathrm{S}$, while moderate-weak correlations $\left(\mathrm{r}^{2}=0.4-0.6\right)$ between the $\mathrm{Li}-\mathrm{Mg}, \mathrm{Zn}-\mathrm{Cu}-\mathrm{Mn}$ and $\mathrm{Rb}-\mathrm{U}$ element pairs. Whereas a negative correlation is obtained between $\mathrm{Li}$ and $\mathrm{Na}$, moderate-weak negative correlations exist between the Li-S, B-CaO and Na-Sr element pairs. Principal component analyses on the correlation matrix yielded eigen- 


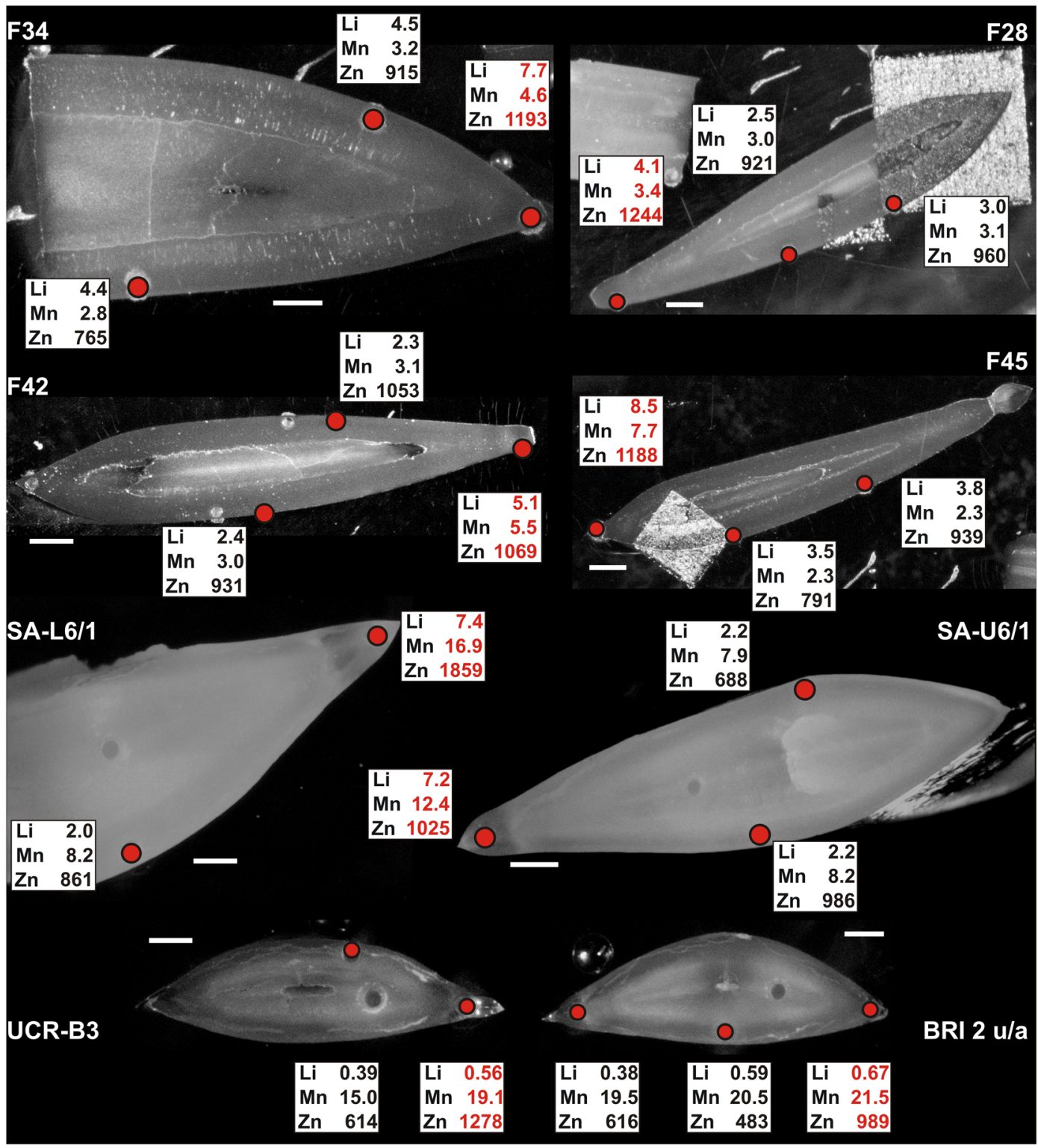

Fig. 6 Variation in trace element concentrations of Li, Mn and Zn. Note that all the teeth from the different localities are more enriched in these elements at the lateral edge where serration occurs, relative to other part of the enameloid. This may imply that $\mathrm{Li}$ and $\mathrm{Mn}$ may also play a role in tooth formation similarly to
Zn (see text). Samples: F28, F34, F42, F45 are from Fiji. SA-L6/1 and $\mathrm{U6} / 1$ are different teeth of the same specimen from South Africa; UCR-B3 tooth from Lake Nicaragua; BRI 2u/a tooth from Brisbane River (Australia)

$(n=22)$ (see also Supplementary Table 1 in Online Resource 2).

\section{Bull shark teeth from other locations}

Also bull shark teeth from South Africa, Lake Nicaragua, Brisbane River, Tonga and Florida were analysed for trace element compositions (see also 
Supplementary Table 3 in Online Resource 2). Enameloid values represent the average of 2-3 spot analyses, while dentine was analysed only once for each tooth. For these teeth the more sensitive sector-field LAICP-MS was used (see Online Resource 3), hence a lower detection limit and better precision is given for elements at low concentrations. Therefore, these teeth were also analysed for the whole rare earth element (REE) series. The results of total REE concentrations reported here are between 2.3 and $22.8 \mathrm{ppb}$. These teeth also have differences in concentrations between enameloid and dentine, which is most apparent in the cases of $\mathrm{Na}, \mathrm{Mg}$, and $\mathrm{Zn}$. Some elements clearly show variations that relate to the given locality (Fig. 3b). The most notable differences relative to the Fiji teeth are higher $\mathrm{Ba}$ and lower, barely detectable Ni concentrations in all of these samples.

The oxygen isotopic compositions of the bull shark teeth cover a range between 18.0 and $22.5 \%$. Analyses for both enameloid and dentine have been made for teeth from the different localities (for details see also Supplementary Table 4 in Online Resource 2). Interestingly, multiple analyses of the teeth from the same individuals give different results. For the South African and Lake Nicaragua specimens, enameloid and dentine have the same values $(21.9 \pm 0.6 \%, n=14$ vs. $22.0 \pm 0.3 \%$ o $n=7$, and $18.5 \pm 0.7 \%$ o, $n=4$ vs. $18.6 \pm$ $0.1 \%, n=2$, respectively). In contrast, teeth of the two juveniles from the Brisbane River have one permil offsets with dentine always more enriched in ${ }^{18} \mathrm{O}(20.8$ $\pm 0.0 \%$ o, $n=2$ vs. $21.7 \pm 0.2 \%, n=2$ and $21.2 \pm 0.5 \%$ o, $n=$ 4 vs. $22.2 \pm 0.3 \%$ o, $n=4)$. For the other sharks kept in the aquarium, where local freshwater was used, lower $\delta^{18} \mathrm{O}$ values of between 14.1 and $15.4 \%$ have been measured (Fig. 7).

\section{Water samples}

The water samples from Fiji clearly reflect differences between seawater and freshwater with respect to their trace element and oxygen isotopic compositions. Seawater and waters from rivers close to the river mouth have higher $\mathrm{Li}, \mathrm{Na}, \mathrm{Mg}, \mathrm{Ca}, \mathrm{Sr}$ concentrations, while most of the river samples were higher in $\mathrm{Ba}, \mathrm{Mn}$, and Zn.

Seawater oxygen isotope composition was measured at $0 \%$, while in some lagoons the water values have a range between -1.5 and $-1.7 \%$. River water $\delta^{18} \mathrm{O}$ values are between -2.8 and $-6.0 \%$. Water samples from the Budapest aquarium have a range between -5.3 and $-7.6 \%$, while the Brisbane River has a value of $1.4 \%$ (see Supplementary Tables 4 and 5 in Online Resource 2).

\section{Discussion}

Major and trace element compositions

The major element content $\left(\mathrm{CaO}\right.$ and $\left.\mathrm{P}_{2} \mathrm{O}_{5}\right)$ and the $\mathrm{Ca} /$ $\mathrm{P}$ ratios of the Fiji teeth are in the general range of concentrations for bio-apatite (Elliott 2002; Skinner and Jahren 2007), but as a major element, $F$ is present too. This latter is common for shark teeth and it agrees with their mineralogical composition of fluor-apatite (Moller et al. 1975; Daclusi and Kerebel 1980).

The measured elemental variations in the Fiji teeth, including the higher $\mathrm{Na}, \mathrm{Mg}$, but lower $\mathrm{F}, \mathrm{Ca}$, and $\mathrm{Zn}$ in the dentine (Fig. 4) can be related to the different organic matter contents and different crystals and crystal size between the enameloid and dentine. This may also explain the relatively large $\mathrm{rsd} \%$ within individual teeth, where the different laser-ablation spots could have integrated parts with different organic matter content. This is likely the case for $\mathrm{Zn}$, which is enriched only at the very external part of the enameloid and its concentration decreases exponentially towards the inside of the teeth (Fig. 5). The positive correlation between $\mathrm{Zn}, \mathrm{Cu}$, and Mn would indicate similar behaviour for these elements (Supplementary Table 2 in Online Resource 2), however the low concentration of $\mathrm{Cu}$ and $\mathrm{Mn}$ did not allow elemental mapping by EMPA, but this was possible for $\mathrm{Zn}$.

Seawater in general has higher $\mathrm{F}, \mathrm{Na}, \mathrm{Mg}$, and $\mathrm{Sr}$ content compared to freshwater, while $\mathrm{Ba}, \mathrm{Mn}$, and $\mathrm{Fe}$ may have higher concentration in river waters (White 1998; Bruland and Lohan 2003; Gaillardet et al. 2003). The water analyses from Fiji's natural waters generally confirm this, although the F content was not analysed for, and $\mathrm{Fe}$ and $\mathrm{Mn}$ had larger variation in the river waters. Nevertheless, these elements can be discriminative between habitats in marine and freshwater environments. Some studies, however, showed that F concentration in enameloid for certain species decouples from the environment and both marine and freshwater specimens may have high $\mathrm{F}$ content as it is an element essential for the bioprecipitation of fluor-apatite (Daclusi and Kerebel 1980; LeGeros and Suga 1980; 
Fig. 7 (a) Oxygen isotopic composition of shark teeth. Red and open triangles are enameloid and dentine analyses,

respectively, while grey triangles are data from literature with some fossil examples too (Vennemann et al. 2001; Kocsis et al. 2007, 2009; Zacke et al. 2009; Klug et al. 2010). The vertical grey bar indicate a general transition between expected marine (high) versus freshwater (low) oxygen isotopic compositions i.e., brackish environment. However note that depending on temperature and water isotopic composition these conditions can overlap. For example teeth formed in rivers/lakes that have high water $\delta^{18} \mathrm{O}$ values would result in high $\delta^{18} \mathrm{O}_{\text {phosphate }}$ in the teeth. See the example of the Brisbane River teeth $\left(\delta^{18} \mathrm{O}_{\text {water }}=\right.$ $1.4 \%$ ). (b) Plots of oxygen isotopic compositions of phosphate versus water and their relation in the function of temperature. Black dashed lines are isotherms calculated from Lécuyer et al. (2013). Note that the $\delta^{18} \mathrm{O}$ values of the teeth are fixed and they might be moved vertically according to the possible water isotopic composition, but still in the frame of acceptable temperature

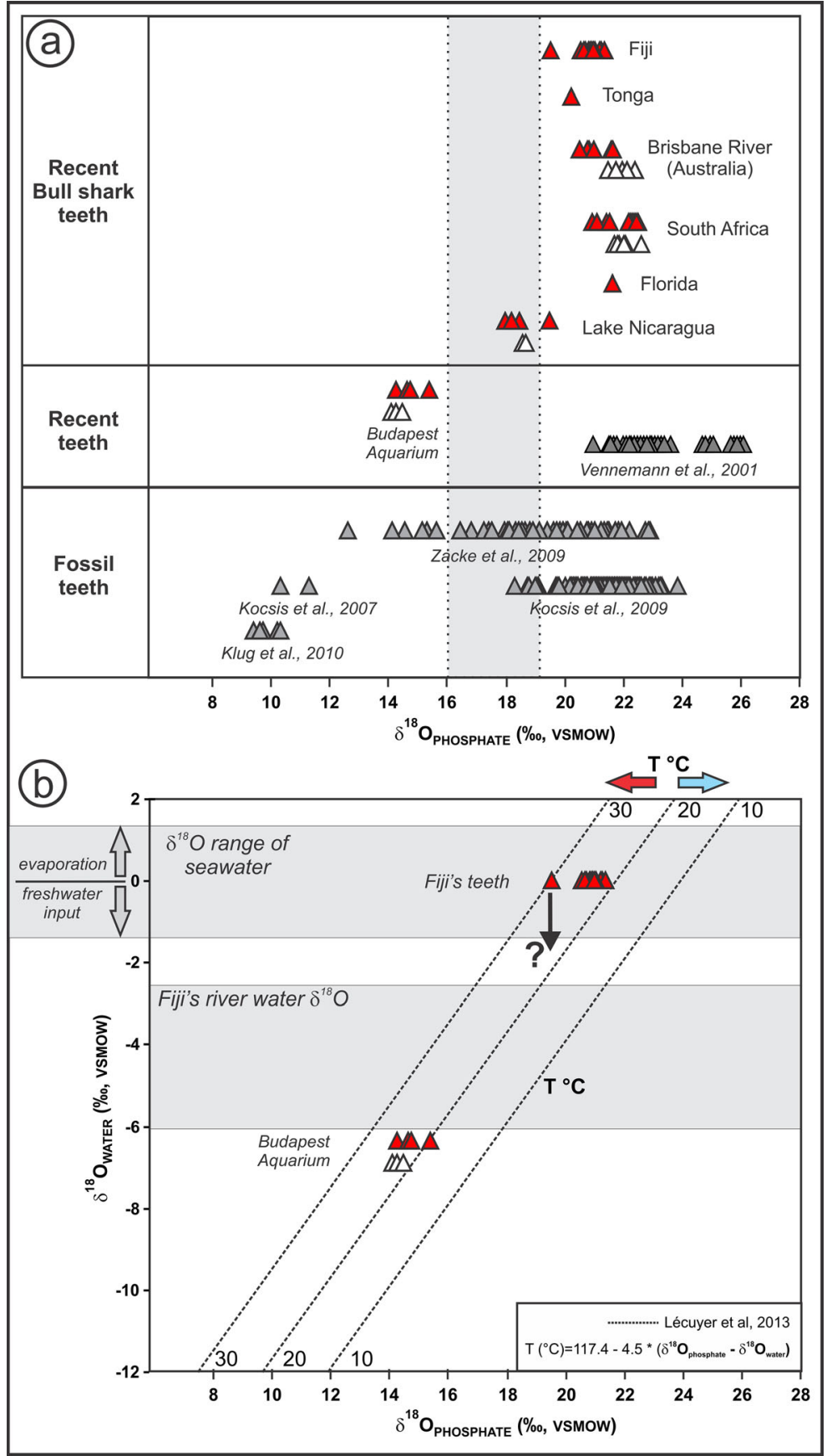

Suga et al. 1986; Miake et al. 1991). Moreover, F and Fe concentrations in enameloid were found to vary as a function of species, which links these elements to the phylogeny of the fish (Suga et al. 1983, 1993). In contrast, many studies successfully used the $\mathrm{Sr} / \mathrm{Ba}$ ratio in otoliths (e.g., McCulloch et al. 2005) and shark vertebra (Tillett et al. 2011) to trace a diadromous habitat, and higher ratios were reported for specimens from marine environments.

Boxplots of these discriminative elements for the Fiji teeth are given in Fig. $3 \mathrm{a}$ and while there are some specimens that clearly differ in value and might indicate different environments of teeth formation, for none of the teeth was a good positive correlation found between 
$\mathrm{F}, \mathrm{Na}, \mathrm{Mg}, \mathrm{Sr}$, nor a negative correlation of $\mathrm{F}$ with $\mathrm{Ba}$, $\mathrm{Mn}$, or $\mathrm{Fe}$ concentrations. However, other teeth from bull sharks of different places are clearly distinct from the Fiji data, as is clearly exemplified by a $\mathrm{Sr} / \mathrm{Ba}$ versus $\mathrm{Mn} / \mathrm{Fe}$ plot (Fig. 3b). The high $\mathrm{Sr} / \mathrm{Ba}$ and low $\mathrm{Mn} / \mathrm{Fe}$ ratios in the Fiji teeth are due to their extremely low $\mathrm{Ba}$, high Fe and relatively low Mn concentrations compared to the other teeth. With these values, the Fiji teeth represent one end member of the data spread, while the teeth likely formed while the sharks were in rivers and lakes are expectedly on the other end of this line (Fig. 3b). Based on these data together with the high F and $\mathrm{Na}$ concentrations in the Fiji teeth, any clear indication for freshwater habitat can be discarded for these sharks.

The cluster-analyses of the eighteen elements suggest six groups of teeth among the Fiji teeth (Online Resource 4). Whether these groups can be related to different nursing or feeding grounds during the months of absence of the sharks at the SRMR needs further investigations. The measured trace element content from the different rivers, lagoons, and seawaters unfortunately does not allow a link between the clustergroups and the different localities. Detailed study is necessary on potential lagoons, bays, and river mouths in order to assess possible connections to different breeding/dwelling grounds.

\section{Oxygen isotope compositions}

From each trace element-derived cluster group, shark teeth were prepared for oxygen isotope analyses in order to check whether compositions different from those in equilibrium with seawater can be detected. The natural waters in Fiji vary from seawater with a value of $0 \%$ to river samples of $-6 \%$ (Supplementary Table 4 in Online Resource 2). The climate is tropical and warm most of the year with precipitation of about $2900 \mathrm{~mm} /$ year, with higher average rainfall between December and April during the wet-warm season (Singh and Aung 2008). The seawater temperature at this time varies between 27 and $30.5^{\circ} \mathrm{C}$ degrees at the coast, while during the drycool season it decreases to $24-25.5^{\circ} \mathrm{C}$ degrees (Singh and Aung 2008).

By plotting the oxygen isotope compositions of phosphate versus water with the calculated temperature isotherms following the equation of Lécuyer et al. $(2013)\left[\mathrm{T}\left({ }^{\circ} \mathrm{C}\right)=117.4-4.5 \times\left(\delta^{18} \mathrm{O}_{\text {phosphate }}\right.\right.$ $\delta^{18} \mathrm{O}_{\text {water }}$ ) (Fig. $7 b$ ) it becomes clear that most of the
Fiji teeth were grown in a marine environment. Moreover, no relationships have been recognized between the oxygen isotopic composition of the teeth and their trace element clusters. Only one tooth (F4) had slightly lower isotopic composition compared to the rest. This might have developed when the shark migrated closer to a river mouth, where the water isotopic composition could be as low as $-2 \%$, but it could equally be related to tooth formation in warmer waters (cf., Fig. 7b). There is no indication for a freshwater habitat from the trace element analyses of this tooth either.

By comparing the $\delta^{18} \mathrm{O}$ values of the Fiji teeth with those of other sharks it becomes apparent that their values are similar to those of sharks that lived in seawater (Fig. 7a, Vennemann et al. 2001). This is true for other bull shark teeth from Tonga, South Africa and Florida. Exceptions are the teeth that were sampled from juvenile sharks in the Brisbane River in Australia, where the obtained $\delta^{18} \mathrm{O}$ values are in the range of expected marine habitat (Fig. 7a). This can be explained by either formation in seawater, even if the sharks were caught in the river, or also by freshwater origin as the Brisbane River water yielded positive $\delta^{18} \mathrm{O}$ value of $1.4 \%$ at the time of sampling (Supplementary Table 4 in Online Resource 2). Here the offset in $\delta^{18} \mathrm{O}$ values between enameloid and dentine may reflect the rapid short-term changes in environmental conditions (i.e., influence of tide).

Teeth from the juvenile bull shark from Lake Nicaragua have lower values indicating a freshwater or at least brackish habitat. Not surprisingly the lowest $\delta^{18} \mathrm{O}_{\text {phosphate }}$ values were measured for teeth of sharks that were kept in an aquarium, clearly reflecting the low ${ }^{18} \mathrm{O}$-source of freshwater used for preparing "seawater" for these tanks (Fig. 7). For some fossil shark teeth even lower $\delta^{18} \mathrm{O}_{\text {phosphate }}$ values were measured, which are clearly compatible with a freshwater habitat (Kocsis et al. 2007; Klug et al. 2010; Fischer et al. 2011) or indicate large amounts of freshwater influx into ancient seas (Zacke et al. 2009; Fischer et al. 2012) (Fig. 7a).

\section{Zinc concentrations}

The relatively large variation in the $\mathrm{Zn}$ content between the teeth is likely related to the concentration decline from the edge of the enameloid towards the inner parts. Hence it is due to measurement spots enclosing different parts of this gradient. The element maps and profiles 
however, show that the teeth with different $\mathrm{Zn}$ concentrations at the outside have very similar $\mathrm{Zn}$ distributions in their enameloid (Fig. 5). The high $\mathrm{Zn}$ concentrations (up to $1330 \mathrm{ppm}$ ) in the external layers of the enameloid, found both in teeth from bull sharks from Fiji and other locations, are a surprising finding because at first these may link to freshwater habitat.

Several studies have investigated trace metal contents of different types of sharks, many focussing on soft tissues such as muscle, liver or kidney and they reported concentrations that varied from species and regions but generally were under $100 \mathrm{ppm}$ (Marcovecchio et al. 1991; Turoczy et al. 2000; Domi et al. 2005; Cornish et al. 2007; McMeans et al. 2007). A similar concentration range was measured from jaw cartilage (Edmonds et al. 1996). In contrast, $\mathrm{Zn}$ concentrations in freshwater fish vary much more depending on the local $\mathrm{Zn}$ source. Fish from lakes that were affected by mining industry or other anthropologic activity have values as high as $600 \mathrm{ppm}$ in their soft tissues and bones (Kraemer et al. 2005; Staniskiene et al. 2006).

$\mathrm{Zn}$ is an essential micronutrient for organisms, but it can be toxic for water organisms when environmental concentrations are high (e.g., Frassinetti et al. 2006). Zn in fish either derives from direct contact with the ambient water or from dietary uptake. For waterborne Zn, gills and intestines are the two major sites for the uptake. As the extreme concentrations are observed at the very edge of the teeth (Fig. 5), one explanation may be the contact with the ambient water. However, relative to the analysed water samples from Fiji (seawater $12 \mathrm{ppb}$ and the max. river water $235 \mathrm{ppb}$ ) the teeth would indicate an enrichment factor of $10^{4}-10^{5}$ and $10^{3}$ relative to seawater and river water, respectively. Hence, again the origin of waterborne $\mathrm{Zn}$ in the teeth would be more realistic for the freshwater environment. Assuming a major dietary source for $\mathrm{Zn}$ would involve prey highly enriched in $\mathrm{Zn}$ as well as higher $\mathrm{Zn}$ concentration in dentine, which is not the case here.

In Fiji Zn concentrations of sediments and shellfish were measured in Laucala Bay and Great Astrolabe Lagoon (Morrison et al. 1997, 2001; Morrison and Naqasima 1999) in order to examine the effects of anthropologic pollutions. However, these studies showed no real impact on the environment and $\mathrm{Zn}$ concentrations were found to be below $160 \mathrm{ppm}$ in shellfish. These values are too low compared to the $\mathrm{Zn}$ concentrations of the Fiji shark teeth. Long term accumulation of $\mathrm{Zn}$ could not resolve the dilemma as shark teeth are replaced very quickly. Therefore, waterborne or dietary Zn cannot explain the high $\mathrm{Zn}$ content.

The most plausible explanation for the high $\mathrm{Zn}$ concentration in Fiji teeth is the maturation process of teeth in general. In higher vertebrates it was shown that during enamel matrix development two protease enzymes were secreted: at first enamelysin (MMP-20) and at later stage kallikrein 4 (KLK4) (Lu et al. 2008). Both enzymes are required for the growth of apatite crystallites (Lu et al. 2008; Goettig et al. 2010). Especially, KLK4 is imperative for the formation of large, well-mineralized enamel crystals (Simmer et al. 2009) and it degrades the organic matrix following the cessation of enamel protein secretion ( $\mathrm{Lu}$ et al. 2008). The interesting fact is that human KLK4 induces crystallization in the presence of zinc (Debela et al. 2006). Therefore, the high $\mathrm{Zn}$ concentration only at the edge of shark tooth enameloid could indicate similar enzyme related processes. This is in agreement with the fact that the most mineralized enameloid part appears at the serrations, which has the highest $\mathrm{Zn}$ concentrations (Fig. 6). Here, Li and $\mathrm{Mn}$ are also more enriched, hence these elements may also be related to the organic removal and crystallization processes by the KLK4 enzyme or some of its precursor existing in the cartilaginous fish (i.e., chondrichthyans).

\section{Conclusions}

Previous attempts that used electronic tagging methods to find habitats where adult bull sharks encountered at the SRMR go for parturition at the end of a calendar year were not successful in that regard (Brunnschweiler et al. 2010; Brunnschweiler and Barnett 2013). Here we focused on the trace element and oxygen isotopic compositions of adult bull sharks' teeth that also did not pinpoint exactly where the species goes for reproduction. However the data clearly confirm a marine habitat for these specimens, at least during the time when the teeth analysed in this study were formed. Given the rapid tooth replacement rate in sharks it remains, however, possible that adult bull sharks penetrate freshwater habitats for short time periods (hours to days) that do not allow detecting a freshwater signal in their teeth.

Trace element compositions of the 49 Fiji teeth analysed showed relatively high $\mathrm{Na}, \mathrm{Mg}, \mathrm{Sr}$, and $\mathrm{F}$ and low Ba concentrations supporting a marine environment without any signs of freshwater habitat. Cluster-analyses of 18 chemical variables indicated the presence of six 
different groups of teeth from Fiji, which may be related to different nursing or feeding grounds. The small number of water samples analysed did not allow a further distinction of such sites, and future studies are required to verify this hypothesis. Analyses of the phosphate oxygen isotopic compositions of a representative set of teeth from each cluster-group are compatible with formation in the marine environment of Fiji (i.e., temperature and seawater isotopic composition). No direct relationship is apparent between trace element clusters and the oxygen isotope data.

Surprisingly, all bull shark teeth had unexpectedly high $\mathrm{Zn}$ concentration, which is likely to be related to enzyme-mediated enameloid maturation. Comparison of the Fiji data to chemical and isotopic compositions of other bull shark teeth around the world and to teeth of other sharks kept in aquarium supports further the interpretations presented here.

Acknowledgements We thank the staff of Beqa Adventure Divers for logistical support and collecting the teeth at the Shark Reef Marine Reserve. The following researchers and institutes are gratefully acknowledged for the supply of shark teeth from different regions: N. Hammerschlag - Rosenstiel School of Marine and Atmospheric Science, Florida, USA; R. Pillans - University of Queensland, Australia; G. Cliff - Natal Sharks Board, South Africa; School of Biology, University of Costa Rica; and Tropicarium Budapest, Hungary. L.K. received support from the Swiss National Science Foundation (Swiss National Foundation-Ambizione PZ00P2_126407/1) when this research was realised. J.M.B. was supported by the Shark Foundation Switzerland (http://www. shark.ch/). J. Earle is acknowledged for proofreading the manuscript.

\section{References}

Bruland KW, Lohan MC (2003) Controls of Trace Metals in Seawater. In: Holland HD, Turekian KK (eds) Treatise on Geochemistry, vol. 6. pp 23-47

Brunnschweiler JM (2010) The shark reef marine reserve: a marine tourism project in Fiji involving local communities. J Sustain Tour 18:29-42

Brunnschweiler JM, Baensch H (2011) Seasonal and long-term changes in relative abundance of bull sharks from a tourist shark feeding site in Fiji. PLoS ONE 6(1):e16597

Brunnschweiler JM, Barnett A (2013) Opportunistic visitors: long-term behavioural response of bull sharks to food provisioning in Fiji. PLoS ONE 8(3):e58522

Brunnschweiler JM, Queiroz N, Sims DW (2010) Oceans apart? Short-term movements and behaviour of adult bull sharks Carcharhinus leucas in Atlantic and Pacific Oceans determined from pop-off satellite archival tagging. J Fish Biol 77: $1343-1358$
Brunnschweiler JM, Abrantes KG, Barnett A (2014) Longterm changes in species composition and relative abundances of sharks at a provisioning site. PLoS ONE 9(1):e86682

Compagno LJV (1984) FAO Species Catalogue, Vol. 4. Sharks of the World. An annotated and illustrated catalogue of shark species known to date. FAO Fish Synop (125) 4(1): i-viii, 1250, 4(2): i-x, 251-655

Cornish AS, Ng WC, Ho VCM, Wong HL, Lam JCW, Lam PKS, Leung KMY (2007) Trace metals and organochlorines in the bamboo shark Chiloscyllium plagiosum from the southern waters of Hong Kong, China. Sci Total Environ 376:335-345

Crowson RA, Showers WJ, Wright EK, Hoering TC (1991) Preparation of phosphate samples for oxygen isotope analysis. Anal Chem 63:2397-2400

Cruz-Martínez A, Chiappa-Carrara X, Arenas-Fuentes V (2005) Age and growth of the bull shark, Carcharhinus leucas, from southern gulf of Mexico. J Northwest Atl Fish Sci 35:367374

Curtis TH, Adams DH, Burgess GH (2011) Seasonal distribution and habitat associations of bull sharks in the Indian river lagoon, Florida: a 30-year synthesis. Trans Am Fish Soc 140:1213-1226

Daclusi G, Kerebel LM (1980) Ultrastructural study and comparative analysis of fluoride content of enameloid in sea-water and fresh-water sharks. Arch Oral Biol 25:145-151

Dahm S, Risnes S (1999) Comparative infrared spectroscopic study of hydroxide and carbonate absorption bands in spectra of shark enameloid, shark dentin, and a geological apatite. Calcif Tissue Int 65:459-465

Debela M, Magdolen V, Grimminger V, Sommerhoff C, Messerschmidt A, Huber R, Friedrich R, Bode W, Goettig P (2006) Crystal structures of human tissue kallikrein 4: activity modulation by a specific zinc binding site. J Mol Biol 362:1094-1107

Dettman DL, Kohn MJ, Quade J, Ryerson FJ, Ojha TP, Hamidullah S (2001) Seasonal stable isotope evidence for a strong Asian monsoon throughout the past 10.7 m.y. Geology 29:31-34

Domi N, Bouquegneau JM, Das K (2005) Feeding ecology of five commercial shark species of the Celtic Sea through stable isotope and trace metal analysis. Mar Environ Res 60:551-569

Edmonds JS, Shibata Y, Lenanton RCJ, Caputi N, Morita M (1996) Elemental composition of jaw cartilage of gummy shark Mustelus antarcticus Günther. Sci Total Environ 192: $151-161$

Elliott J (2002) Calcium phosphate biominerals. In: Kohn JM, Rakovan J, Hughes JM (eds) Review in Mineralogy and Geochemistry, vol. 48. pp 427-454

Epstein S, Mayeda TK (1953) Variations of the ${ }^{18} \mathrm{O} /{ }^{16} \mathrm{O}$ ratio in natural waters. Geochim Cosmochim Acta 4: 213-224

Fischer J, Voigt S, Schneider JW, Buchwitz M, Voigt S (2011) A selachian freshwater fauna from the Triassic of Kyrgyzstan and its implication for Mesozoic shark nurseries. J Vertebr Paleontol 31:937-953

Fischer J, Voigt S, Franz M, Schneider JW, Joachimski MM, Tichomirowa M, Götze J, Furrer H (2012) Palaeoenvironments of the late Triassic Rhaetian Sea: implications from oxygen and strontium isotopes of hybodont 
shark teeth. Palaeogeogr Palaeoclimatol Palaeoecol 353355:60-72

Frassinetti S, Bronzetti G, Caltavuturo L, Cini M, Croce CD (2006) The role of zinc in life: a review. J Environ Pathol Toxicol Oncol 25:597-610

Gaillardet J, Viers J, Dupré B (2003) Trace Elements in River Waters. In: Holland HD, Turekian KK (eds) Treatise on Geochemistry, vol. 5. pp 225-272

Gillanders BM, Sanchez-Jerez P, Bayle-Sempere J, Ramos-Espla A (2001) Trace elements in otoliths of the two-banded bream from a coastal region in the south-west Mediterranean: are there differences among locations? General trace element chemistry. J Fish Biol 59:350-363

Goettig P, Magdolen V, Brandstetter H (2010) Natural and synthetic inhibitors of kallikrein-related peptidases (KLKs). Biochimie 92:1546-1567

Heupel MR, Simpfendorfer CA (2008) Movement and distribution of young bull sharks Carcharhinus leucas in a variable estuarine environment. Aquat Biol 1:277-289

Heupel MR, Yeiser BG, Collins AB, Ortega L, Simpfendorfer CA (2010) Long-term presence and movement patterns of juvenile bull sharks, Carcharhinus leucas, in an estuarine river system. Mar Freshw Res 61:1-10

Hoefs J (2004) Stable Isotope Geochemistry, 5th edn. Springer, Berlin, p 340

Kemp NE (1999) Integumentary system and teeth. In: Hamlett WC (ed) Sharks, skates, and rays: The biology of elasmobranch fishes. The John Hopkins University Press, Baltimore, pp 43-68

Klug S, Tütken T, Wings O, Pfretzschner H-U, Martin T (2010) A Late Jurassic freshwater shark assemblage (Chondrichthyes, Hybodontiformes) from the southern Junggar Basin, Xinjiang, Northwest China. Palaeobio Palaeoenviron 90: 241-257

Koch PL, Halliday AN, Walter LM, Stearley RF, Huston TJ, Smith GR (1992) Sr isotopic composition of hydroxyapatite from recent and fossil salmon - the record of lifetime migration and diagenesis. Earth Planet Sci Lett 108:277-287

Koch PL, Tuross N, Fogel ML (1997) The effects of sample treatment and diagenesis on the isotopic integrity of carbonate in biogenic hydroxylapatite. J Archaeol Sci 24:417-429

Kocsis L, Vennemann TW, Fontignie D (2007) Migration of sharks into freshwater systems during the Miocene and implications for Alpine paleoelevation. Geology 35:451-454

Kocsis L, Vennemann TW, Hegner E, Fontignie D, Tütken T (2009) Constraints on Miocene oceanography and climate in the Western and Central Paratethys: O-, Sr-, and Ndisotope compositions of marine fish and mammal remains. Palaeogeogr Palaeoclimatol Palaeoecol 271:117-129

Kolodny Y, Luz B, Navon O (1983) Oxygen isotope variations in phosphate of biogenic apatites, I. Fish bone apatiterechecking the rules of the game. Earth Planet Sci Lett 64: 398-404

Kraemer LD, Campbell PGC, Hare L (2005) Dynamics of Cd, Cu and $\mathrm{Zn}$ accumulation in organs and sub-cellular fractions in field transplanted juvenile yellow perch (Perca flavescens). Environ Pollut 138:324-337

Lécuyer C, Amiot R, Touzeau A, Trotter J (2013) Calibration of the phosphate $\delta^{18} \mathrm{O}$ thermometer with carbonate-water oxygen isotope fractionation equations. Chem Geol 347: $217-226$
LeGeros RZ, Suga S (1980) Crystallographic nature of fluoride in enameloids of fish. Calcif Tissue Int 32:169-174

Longinelli A, Nuti S (1973) Oxygen isotope measurements from fish teeth and bones. Earth Planet Sci Lett 20:337-340

Lu Y, Papagerakis P, Yamakoshi Y, Hu JC-C, Bartlett JD, Simmer JP (2008) Functions of KLK4 and MMP-20 in dental enamel formation. Biol Chem 389:695-700

MacKenzie KM, Palmer MR, Moore A, Ibbotson AT, Beaumont WRC, Poulter DJS, Trueman CN (2011) Locations of marine animals revealed by carbon isotopes. Nat Sci Rep 1(21):1-6

Marcovecchio JE, Moreno VJ, Perez A (1991) Metal accumulation in tissues of sharks from the Bahia Blanca estuary, Argentina. Mar Environ Res 31:263-274

McCulloch M, Cappo M, Aumend J, Muller W (2005) Tracing the life history of individual barramundi using laser ablation MCICP-MS Sr-isotopic and $\mathrm{Sr} / \mathrm{Ba}$ ratios in otoliths. Mar Freshw Res 56:637-644

McMeans BC, Borga K, Bechtol WR, Higginbotham D, Fisk AT (2007) Essential and non-essential element concentrations in two sleeper shark species collected in arctic waters. Environ Pollut 148:281-290

Miake Y, Aoba T, Moreno EC, Shimoda S, Prostak K, Suga S (1991) Ultrastructural studies on crystal-growth of enameloid minerals in elasmobranch and teleost fish. Calcif Tissue Int 48:204-217

Moller IJ, Melsen B, Jensen SJ, Kirkegaard E (1975) A histological, chemical and X-ray diffraction study on contemporary (Carcharias glaucus) and fossilized (Macrota odontaspis) shark teeth. Arch Oral Biol 20:797-802

Morrison RJ, Naqasima MR (1999) Fiji's Great Astrolabe Lagoon: baseline study and management issues for a pristine marine environment. Ocean Coast Manag 42:617-636

Morrison RJ, Gangaiya P, Naqasima MR, Naidu R (1997) Trace metal studies in the Great Astrolabe Lagoon, Fiji, a pristine marine environment. Mar Pollut Bull 34:353-356

Morrison RJ, Narayan SP, Gangaiya P (2001) Trace element studies in Laucala Bay, Suva, Fiji. Mar Pollut Bull 42:397404

Motta PJ, Wilga CD (2001) Advances in the study of feeding behaviors, mechanisms, and mechanics of sharks. Environ Biol Fish 60:131-156

Outridge PM, Chenery SR, Babaluk JA, Reist JD (2002) Analysis of geological $\mathrm{Sr}$ isotope markers in fish otoliths with subannual resolution using laser ablation-multicollectorICP-mass spectrometry. Environ Geol 42:891-899

Rasalato E, Maginnity V, Brunnschweiler JM (2010) Using local ecological knowledge to identify shark river habitats in Fiji (South Pacific). Environ Conserv 37:90-97

Shephard S, Trueman C, Rickaby R, Rogan E (2007) Juvenile life history of NE Atlantic orange roughy from otolith stable isotopes. Deep-Sea Res Pt I 54:1221-1230

Simmer JP, Hu Y, Lertlam R, Yamakoshi Y, Hu JCC (2009) Hypomaturation enamel defects in Klk4 knockout/LacZ knockin mice. J Biol Chem 284:19110-19121

Simpfendorfer CA, Freitas GG, Wiley TR, Heupel MR (2005) Distribution and habitat partitioning of immature bull sharks (Carcharhinus leucas) in a southwest Florida estuary. Estuaries 28:78-85

Singh A, Aung T (2008) Salinity, Temperature and Turbidity Structure in the Suva Lagoon, Fiji. Am J Environ Sci 4: 266-275 
Skinner WCH, Jahren AH (2007) Biomineralization. In: Holland HD, Turekian KK (eds.) Treatise on Geochemistry, Ch. 8.04, pp 1-69

Staniskiene B, Matusevicius P, Budreckiene R, Skibniewska KA (2006) Distribution of heavy metals in tissues of freshwater fish in Lithuania. Pol J Environ Stud 15:585-591

Suga S, Taki Y, Wada K (1983) Fluoride concentration in the teeth of perciform fishes and its phylogenetic significance. Jpn J Ichthyol 30:81-93

Suga S, Taki Y, Wada K (1986) Biological significance of fluoride in fish teeth. Stud Environ Sci 27:285-297

Suga S, Taki Y, Ogawa M (1993) Fluoride and iron concentrations in the enameloid of lower teleostean fish. J Dent Res 72:912-922

Tillett BJ, Meekan MG, Parry D, Munksgaard N, Field IC, Thorburn D, Bradshaw CJA (2011) Decoding fingerprints: elemental composition of vertebrae correlates to age-related habitat use in two morphologically similar sharks. Mar Ecol Prog Ser 434:133-142

Tillett BJ, Meekan MG, Field IC, Thorburn DC, Ovenden JR (2012) Evidence for reproductive philopatry in the bull shark Carcharhinus leucas. J Fish Biol 80:2140-2158
Tsukamoto K, Watanabe S, Kuroki M, Aoyama J, Miller MJ (2014) Freshwater habitat use by a moray eel species, Gymnothorax polyuranodon, in Fiji shown by otolith microchemistry. Environ Biol Fish 97: 1377-1385

Turoczy NJ, Laurenson LJB, Allinson G, Nishikawa M, Lambert DF, Smith C, Cottier JPE, Irvine SB, Stagnitti F (2000) Observations on metal concentrations in three species of shark (Deania calcea, Centroscymnus crepidater, and Centroscymnus owstoni) from Southeastern Australian Waters. J Agric Food Chem 48:4357-4364

Vennemann TW, Hegner E, Cliff G, Benz GW (2001) Isotopic composition of recent shark teeth as a proxy for environmental conditions. Geochim Cosmochim Acta 65:1583-1599

White WM (1998) The Ocean as a Chemical system. Geochemistry, an on-line textbook, vol. 15. pp 645701

Zacke A, Voigt S, Joachimski MM, Gale AS, Ward DJ, Tütken T (2009) Surface-water freshening and highlatitude river discharge in the Eocene North Sea. J Geol Soc 166:969-980 